QAULAN, Vol. 2, No.1, Juni 2021

Rafinita Aditia, Leardership Style....

\title{
LEADERSHIP STYLE AND COMMUNICATION PATTERNS OF ISLAMIC FOUNDATION LEADER IN MANAGING ORGANIZATIONS \\ (Case Study At Tahfidz Abdurrahman Al-Fatih Bengkulu City)
}

\author{
Rafinita Aditia \\ Universitas Bengkulu \\ Email: rafinitaaditiaa@gmail.com
}

\begin{abstract}
The purpose of this study was to analyze and describe how the leadership style and communication patterns of Islamic foundation leader in managing organizations, especially in Tahfidz Abdurrahman Al-Fatih Bengkulu City. The method used in this research is a qualitative method. The type of research used is Field Research (field research) by directly visiting and seeking information directly from the situation where the research was conducted. Data collection in this study was carried out using interviews, observation, and documentation. From the research results, it was found that Ustad Ilham Rahmatun Putra as the leader of Tahfidz Abdurrahman Al-Fatih has his own leadership style and communication pattern in managing organization. Leadership Style which is owned by Ustad Ilham including including The Structuring Style, The Relinquishing Style, and The Equalitarian Style. By implementing these three leadership styles, Tahfidz Abdurrahman Al-Fatih grow and gain the trust of various parties. The communication pattern that occurs in Tahfidz Abdurrahman Al-Fatih is a wheel pattern, so that the leadership power is in a central position and is influential in the process of delivering the message where all running information must first be conveyed to the leadership. In addition, the message flow that occurs in an organizational network includes downward communication, upward communication, horizontal communication, and cross-channel communication.
\end{abstract}

\section{Keywords: Leadership, Organizations, Leadership Style, Communication Patterns}

\section{INTRODUCTION}

An organization or business unit, whether formal or informal, needs a personal leader who can encourage its members to always be productive because the spirit of a leader in an organization is felt to be a role model for other members. The leadership of a dynamic and effective leader is the most basic resource that is difficult to find. Leadership is the most important part of management, this is because leadership is the driving force for the optimization of production factors (human, capital, machines and methods) in an organization or company.

The success of an organization does not only depend on real capital in the form of money, but one of the things that also influences the human resources in the organization. ${ }^{1}$ Because all the materials owned by an organization will not be able to work without the ideas and creativity of the members of the organization who are scattered in various divisions with their respective duties and responsibilities. In almost all organizations, organizational members are important assets and must

\footnotetext{
${ }^{1}$ Husein Umar, "Strategic Management in Action”, 72
} 
QAULAN, Vol. 2, No.1, Juni 2021

Rafinita Aditia, Leardership Style....

be maintained. Therefore, for an organization, the performance level of the members is very influential because of the large demands for optimizing the performance of the members of the organization. One approach in an effort to improve the performance of organizational members is through leadership practices or leadership styles that are reliable and are able to increase the productivity of organizational members.

A leader is often faced with the problem of how to create a situation and conditions in which subordinates can get the satisfaction of their individual needs in doing their job to achieve organizational goals. ${ }^{2}$ Or in other words, how a leader can adjust the desires of subordinates with organizational goals. To be able to adjust these two things a leader must be able to understand the nature of his subordinates. What drives them to do their best, and how to motivate them, resulting in high productivity. A leader in the company must also be able and need to provide motivation to employees so that they can work optimally. Motivation is needed by employees, because with good motivation employees can carry out work in accordance with their responsibilities. ${ }^{3}$

A leader has the capacity to read the situation he faces and adjust the leadership style according to the situation and conditions of the organization, even though this adjustment is only temporary. Every leader has characteristics, habits, dispositions and distinctive personality, which differentiates it from other leaders. In everyday reality there are still questions about the effective leadership style, or how to implement effective leadership in running an organization.

As a private organization that focuses on the social, religious and humanitarian fields, all activities and movements carried out by the Tahfidz Abdurrahman Al-Fatih are certainly inseparable from its leader. Ustad Ilham Rahmatun Putra, S.Thi, M. Ag as the leader of this organization faces a heavy responsibility, for that he must have adequate preparation, both mentally and psychologically in carrying out his duties, especially in dealing with all the problems and challenges faced in creating and provide comfort in the organization. Ustad Ilham's leadership style certainly has a significant effect on enhancing and creating a learning process that is effective (effective) and right on target.

Apart from the leadership style, another thing that is also very influential on an organization is the communication patterns that occur in it. ${ }^{4}$ The communication pattern is a way of delivering messages or information using symbols in the form of symbols or communicating face-

\footnotetext{
2 Kartini Kartono, "Pemimpin dan Kepemimpinan", 39

3 Siti Maisarah Hasibuan, "Pengaruh Kepemimpinan, Lingkungan Kerja dan Motivasi Kerja Terhadap Kinerja”, Jurnal Maneggio, Vol. 1, No. 1, 2018, 73

${ }^{4}$ Khomsahrial Romli, "Komunikasi Organisasi Lengkap", 44
} 
QAULAN, Vol. 2, No.1, Juni 2021

Rafinita Aditia, Leardership Style....

to-face according to the agreement of the members of the organization so that it can change the behavior level of the members of the organization for the better and the message given can be more easily understood. ${ }^{5}$

The application of leadership styles and good communication patterns in the organization in overcoming problems that occur. Based on the explanation above, the author focuses on the preparation of a paper on Leadership Style and Communication Patterns of Islamic Foundation Leaders In Managing Organizations (Case Study At Tahfidz Abdurrahman Al-Fatih).

\section{METHOD}

In this study using a descriptive approach that describes and explains about Leadership Style and Communication Patterns of Islamic Foundation Leaders In Managing Organizations (Case Study At Tahfidz Abdurrahman Al-Fatih).

The method used in this research is a qualitative method. Qualitative method is a method of examining an object, whether in the form of human cultural values, philosophical thought systems, ethical values, values of works of art, a group of people, events or other cultural objects. The purpose of research using descriptive methods is to make descriptions of pictures or paintings systematically and objectively, regarding facts, characteristics, characteristics and relationships between existing elements or certain phenomena. ${ }^{6}$

While the type of research used is Field Research (field research) by directly visiting and seeking information directly from the situation where the research was conducted. This type of research has the nature of explaining the descriptive case study method. Data collection in this study was carried out using interviews, observation, and documentation. The interview implementation technique used by the researcher is the interview the researcher uses is guided free interview, which is to conduct interviews that are relaxed and flexible with the aim that information is not too tense and stiff without intending to rule out seriousness and formal identity in the study. Through this method, researchers get various information related to Leadership Style and Communication Patterns in Tahfidz Abdurrahman Al-Fatih.

The method of observation in this study is used to obtain data related to Leadership Style and Communication Patterns in Tahfidz Abdurrahman Al-Fatih. The purpose of observation is to describe the studied setting, the activities that take place, the people involved in the activity, and the meaning of events seen from their perspective as seen in the events observed. And the

\footnotetext{
5 Onong uchyana, “Dinamika Komunikasi”, 38
} 
QAULAN, Vol. 2, No.1, Juni 2021

Rafinita Aditia, Leardership Style....

documentation method is an assessment of references related to the focus of the research problem. In research that becomes documentation, namely personal documents, photographs, and recordings. ${ }^{7}$

\section{THEORITICAL REVIEW}

\section{Definition Of Leadership Style}

Leadership literally contains the meaning of directing, building or managing, guiding and also showing or influencing. Leaders have responsibility both physically and spiritually for the success of the work activities of those who are led, so that being a leader is not easy and everyone will not have the same in carrying out their leadership. Leadership is a process carried out by a leader in leading an organization and influencing subordinates to achieve organizational goals. The leader is the most important part of the organization, because if the leader carries out the leadership function well, the organization will run well and vice versa.

Meanwhile, a leader certainly has his own leadership style in leading, this style is certainly important because it is the way a leader treats his subordinates. ${ }^{8}$ If subordinates get a sense of comfort, this will have a good impact on the organization and will make it easier to achieve organizational goals.

Communication styles can be viewed as meta-messages contextualize how verbal messages are recognized and interpreted (communications style can also be viwed as a meta-message which contextualizes how verbal messages should acknowladged and interpreted), this definition explain why someone communicates, nothing else communicates as attempts to reflect on his personal identity which can affect perceptions other people against this identity. Communication style can also be interpreted as mix of elements of oral and illustrative communication. Individual verbal messages which is used to communicate expressed in certain words a characterizes the communication style. This includes tone, volume, over all messages be spoken. ${ }^{9}$

Leadership style is a set of characteristics used by leaders to influence subordinates in order to achieve organizational goals. In another sense, leadership style is a pattern of behavior, strategies, or concepts that are often applied by a leader. A leadership style or type of leadership that shows directly and indirectly about a leader's belief in the abilities of his subordinates. That is,

\footnotetext{
${ }^{6}$ Kaelan, "Metode Penelitian Kualitatif Bidang Filsafat", 58

${ }^{7}$ Lexy Moleong, "Metodologi Penelitian Kualitatif", 102

${ }^{8}$ Sentot Imam Wahjono, "Perilaku Organisasi", 266

${ }^{9}$ Hendra Gilang Prasetia, "Hubungan Gaya Komunikasi Pemimpin dengan Kinerja Pegawai di Biro Sosial Sekretariat Daerah Provinsi Kalimantan Timur", Ejournal Ilmu Komunikasi, Vol 1, No 2, 2009, 504
} 
leadership style is behavior and strategy, as a result of a combination of skills, traits, attitudes, which are often applied by a leader when he tries to influence his subordinates.

The definition of leadership styles according to Thoha, namely Leadership Style, is a behavior norm used by a person when that person tries to influence the behavior of others as he sees it. ${ }^{10}$ In addition, Rivai Stating Leadership Style is a set of features used by leaders to influence subordinates so that organizational goals are achieved or it can also be said that leadership style is a pattern of behavior and strategies that are liked and often applied by a leader. Stonner also defines leadership style as the various patterns of behavior favored by leaders in the process of directing and influencing workers.

The leadership style of an organizational leader is inseparable from the style of communication. There are six communication styles including:

a. The Controlling Style: This controlling style of communication is characterized by a desire or intention to limit, coerce and regulate the behavior, thoughts and responses of others. People who use this communication style are known as one-way communicators or oneway communicators.

b. The Equalitarian Style: The equalitarian style of communication is characterized by the enactment of two-way traffic of communication. In this communication style, communication acts are carried out openly. That is, every member of the organization can express ideas or opinions in such an atmosphere, enabling each member of the organization to reach mutual agreement and understanding.

c. The Structuring: This structured communication style takes advantage of verbal messages in writing and verbally in order to establish orders to be carried out, task and job scheduling and organizational structure. Senders pay more attention to the desire to influence others by sharing information about organizational goals, work schedules, rules and procedures that apply in the organization.

d. The Dynamic Style: This dynamic style of communication has an aggressive tendency, because the sender of the message or sender understands that the work environment is action-oriented. The dynamic style of communication is often used by campaigners or supervisors in charge of salesmen.

e. The Relinguishing Style: This communication style reflects a willingness to accept other people's opinions, opinions or ideas, rather than a desire to give orders, even though 
sending messages (sender) has the right to give orders and control others.

f. The Withdrawal Style: The result that arises if this style is used is the weakening of the act of communication, meaning that there is no desire of people who use this style to communicate with other people, because there are some problems or interpersonal difficulties faced by people the. ${ }^{11}$

\section{DEFINITION OF COMMUNICATION PATTERNS}

In the communication process, it can be seen in the form of distinctive patterns seeing how the flow of the communication process is. ${ }^{12}$ The form of communication pattern itself places more emphasis on the network of the direction of information flow, which occurs in conveying information to all parts of the organization and receiving information back. "Experimental analysis of communication patterns suggests that certain arrangements regarding" who speaks to whom "have major consequences for the functioning of the organization.

According to Joseph A. Davito, quoted by Abdullah Masmuh in the book "Organizational Communication in Theory and Practice Perspective" states that there are 5 forms of flow of communication patterns contained in an information network direction within an organization, namely:

\section{a. Circle Pattern}

In this pattern all members of the organization can communicate with other members, they have the power to influence the group, but they do not have clear leadership.

b. Wheel Pattern

In the wheel pattern here has a clear leadership, so the power of the leadership is in a central position and is influential in the process of conveying the message, where all information that runs must first be conveyed to the leadership.

c. Pattern Y

Pattern $\mathrm{Y}$ also has a clear leader in the information flow process. All members involved in it can send and receive messages with others.

d. Chain Pattern

The chain pattern has five levels called upward communication, where the flow of information occurs from upwards and downwards and vice versa.

e. Star Pattern

11 Djuarsa Sendjaja, “Teori Komunikasi”, 413 
The pattern of all channels / stars is a combination and development of a circular pattern in which reciprocal interactions occur between members of the communication without knowing who is the central leader. ${ }^{13}$

When messages flow through official channels defined by the official hierarchy of the organization or by job functions, they correspond to formal communication networks. Messages in formal communication networks usually flow from top to bottom or from bottom to top or from the same level or horizontally and across channels. ${ }^{14}$ There are four main forms of message flow in formal communication networks that follow the lines of communication as described in the organizational structure, namely: 1) downward communication, 2) upward communication, 3) horizontal communication, 4) cross-channel communication.

Downward communication within an organization means that information flows from positions of higher authority to those of lower authority. Usually we assume that information moves from management to employees; however, in most organizations the relationship lies with the management group.

Upward communication in an organization means that information flows from lower levels (subordinates) to higher levels (supervisors). All employees in an organization, except perhaps those in top positions, may communicate upward - that is, any subordinate can either reason or request information from or provide information to someone of higher authority than him. A request or comment directed to an individual whose authority is greater, higher, or broader is the essence of upward communication. Upward communication in an organization means that information flows from a lower level (subordinates) to a higher level (supervisor). All employees in an organization, except perhaps those in top positions, may communicate upward - that is, any subordinate can either reason or request information from or provide information to someone of higher authority than him. A request or comment directed to an individual whose authority is greater, higher, or broader is the essence of upward communication. ${ }^{15}$

Horizontal communication consists of conveying information between peers in the same work unit. The work unit includes individuals who are placed at the same level of authority in the organization and have the same superiors.

12 Aubrey Fisher," Teori-teori Komunikasi", 83

${ }^{13}$ Joseph A. Devito, "Komunikasi Antarmanusia", 383

${ }^{14}$ Muhammad Arni, "Komunikasi Organisasi", 107

${ }^{15}$ Lidia Wati Evelina dan Mia Angeline, "Komunikasi Vertikal Dan Horizontal Dalam Membentuk Gaya Kepemimpinan Berbasis Kearifan Lokal: Studi Pada Binus University", Jurnal Humaniora,Vol. 5, No. 1, 2014, 448 
The last is cross channel communication. In most organizations, there is a desire for members to share information across functional boundaries with individuals who are neither superior nor subordinate to them. ${ }^{16}$ For example, sections such as engineering, research, accounting, and personnel collect data, reports, plan preparation, coordinate activities, and advise managers on the work of employees in all parts of the organization. They cross functional lines and communicate with those with whom they communicate and especially have to promote their ideas. However, they have high mobility in the organization; they can visit other sections or leave their offices just to engage in information communication.

\section{GENERAL DESCRIPTION OF TAHFIDZ ABDURRAHMAN AL-FATIH}

Tahfidz Abdurrahman Al-Fatih is an islamic foundation located on Jl. Sumur Dewa 2 No.28 Sumur Dewa Subdistrict, Selebar District, Bengkulu City. This organization has aims and objectives in the social, religious and humanitarian fields. This organization is a new organization that was founded in July 2020 and officially runs in August 2020. The leader of Tahfidz Abdurrahman Al-Fatih is Ustad Ilham Rahmatun Putra, S.Thi, M. Ag who is a religious and social activist. . The main objectives of this organization are:

a. Social Objectives, namely organizing activities that can have a positive impact on the surrounding social / community, both from an economic and moral and cultural perspective.

b. Religious purposes, organizing activities and syi'ar as well as religious education based on the ideology of Ahlussunnah wal Jama'ah.

c. Humanitarian Objectives, organizing activities which include: Providing assistance to victims of natural disasters, Providing assistance to refugees due to war, Providing consumer protection, Preserving the environment.

The policy of this organization is to help people and people in need, regardless of ethnicity, race, social status, age and whatever the circumstances.

\section{RESULT AND DISCUSSION}

\section{Leadership Style At Tahfidz Abdurrahman Al-Fatih}

As a new organization, Tahfidz Abdurrahman Al-Fatih has its own charm. With an organization that

16 Mochamad Rizki Fauzi Abdurrahman, "Komunikasi Organisasi Vertikal, Horizontal, dan Lintas 
is still very young, it becomes a challenge related to how this organization can be recognized by the public and survive among various similar existing organizations, especially in Bengkulu Province. Of course, this cannot be separated from the leadership style adopted by Ustad Ilham Rahmatun Putra.

As a leader, Ustad Ilham has his own leadership style including The Structuring Style, The Relinquishing Style, and The Equalitarian Style. The Structuring Style is a leadership style in which organizational leaders make use of written and verbal messages to strengthen orders to be carried out, task and job scheduling and organizational structure. This style is inherent in Ustad Ilham as he always coordinates and is directly involved in every process and activity in the organization. It is not uncommon for Ustad Ilham to give messages both verbally and verbally to the organizers of the organization as well as students studying at the organization, besides that Ustad Ilham is also actively using social media in the form of Facebook in conveying all information related to the organization, so that transparency and update of information on the organization become smoother.

The Relinquishing Style is a leadership style in which a leader reflects a willingness to accept other people's suggestions, opinions, ideas rather than the desire to give orders, even though he has the right to do so. This leadership style is also reflected in the nature of Ustad Ilham who is always open to suggestions from others. Even though he is a leader, Ustad Ilham also has a coach who becomes his advisor in his actions.

The leadership style that is also attached to Ustad Ilham as the leader of the organization is The Equalitarian Style. This leadership style is characterized by the enactment of two-way traffic of communication. This can be seen from the leadership style of Ustad Ilham who is always open to any ideas and opinions from members of the organization. Ustad Ilham, as the leader of the organization, also formed a discussion group as a forum for exchanging ideas for the good of the organization. The three leadership styles adopted by the Leader of the Yayasan Cahaya Generasi Islam Foundation, Abdurrahman Al-Fatih, are a combination of excellent leadership styles. With the implementation of these three leadership styles, the organization will develop and gain the trust of various parties.

\section{COMMUNICATION PATTERNS AT TAHFIDZ ABDURRAHMAN AL-FATIH}

Communication patterns that take place within an organization also greatly determine the 
QAULAN, Vol. 2, No.1, Juni 2021

Rafinita Aditia, Leardership Style....

effectiveness and level of achievement of organizational goals. The Islamic Generation Light Foundation Pondok Tahfidz Abdurrahman Al-Fatih is a young organization, therefore the members of the existing organizations are not yet complex. The fulcrum for this organization is still very dependent on its leader, namely Ustad Ilham. In its application, the communication pattern that occurs in this organization is a wheel pattern with clear leadership, so that the leadership power is in a central position and is influential in the process of conveying the message where all running information must first be conveyed to the leadership.

The structural members in this organization only have 14 members. For this reason, many parts of the organization also become other parts. It can be said that the communication that occurred at the Islamic Generation Light Foundation of Pondok Tahfidz Abdurrahman Al-Fatih was cross-channel communication. Where members of the organization share information across functional boundaries with individuals who are not in their superior or subordinate positions. So that everyone can move to each other and concurrent their duties if needed.

In addition, downward communication and upward communication also take place in this organization. The downward communication that occurs includes the delivery of work instructions, explanations from the leadership regarding the importance of implementation, the delivery of information regarding applicable regulations, providing motivation to organizational members, and much more. Communication to it includes the delivery of information about the tasks that have been carried out, addressing obstacles in carrying out tasks, submitting suggestions, submitting complaints, and others. The form of message flow in this organizational network also includes horizontal communication. Horizontal communication is carried out by this organization in the form of improving task coordination, efforts to solve problems and conflicts, sharing information, and fostering relationships through joint activities. The four forms of communication that exist are carried out by the organization led by Ustad Ilham for the sake of a better organization.

\section{EFFENCTIVENESS AND ACHIEVEMENT OF ORGANIZATIONAL GOALS}

The form of organizational communication that took place at the Tahfidz Abdurrahman Al-Fatih can be said to have been effective, but still not perfect. This is based on the fact that all organizational goals have not been achieved and there are still deficiencies on various sides. When viewed from the perspective of Ustad Ilham's leadership style as the leader of the organization, it can be said that the leadership style applied has been effective. Even though he is the leader, Ustad Ilham still accepts suggestions from all parties, including his subordinates. Ustad Ilham also always provides transparency in organizational activities and creates a forum in the form of a discussion group to 
QAULAN, Vol. 2, No.1, Juni 2021

Rafinita Aditia, Leardership Style....

discuss each other for the good of the organization.

The wheel communication pattern that is applied can also be said to be effective. Judging from the absence of complaints from members of the organization regarding the ongoing communication patterns. Leaders and members of the organization feel that this pattern is appropriate, because all members get an equal position in the process of interaction with their leader. Making it easier to convey existing information. In addition, upward, downward and horizontal communication that occurred were also considered effective because the flow of communication messages was running smoothly and was more structured.

The problem with this organization is cross-channel communication. The age of the organization is still relatively young, and the number of members of the organization is still small, so the experience of this organization is still not too much. The members of the organization become overwhelmed in carrying out their duties, because they have to be able to do other tasks as well. This dual assignment makes it difficult for organizational members to determine the focus of activities, so that organizational goals have not been fully achieved. However, over time if the leadership style and communication patterns that are being applied now continue to be used by this organization, the effectiveness and goals of the organization will certainly be achieved properly. It takes more flight hours and more competent organizational resources as well as a lot, to support the success of the organization.

\section{CONCLUSION}

As a new organization, Tahfidz Abdurrahman Al-Fatih has its own charm. With an organization that is still very young, it becomes a challenge related to how this organization can be recognized by the public and survive among various similar existing organizations, especially in Bengkulu Province. This of course cannot be separated from the leadership style adopted by Ustad Ilham Rahmatun Putra.

As a leader, Ustad Ilham has his own leadership style including The Structuring Style, The Relinquishing Style, and The Equalitarian Style. The three leadership styles adopted by the Leader of the Yayasan Cahaya Generasi Islam Foundation, Tahfidz Abdurrahman Al-Fatih, are a combination of excellent leadership styles. By implementing these three leadership styles, the organization will grow and gain the trust of various parties. The communication pattern that occurs in this organization is a clear wheel-to-leader communication pattern, so that the leadership power is in a central position and is influential in the process of delivering the message where all running information must first be conveyed to the leadership. In addition, the message flow that occurs in 
QAULAN, Vol. 2, No.1, Juni 2021

Rafinita Aditia, Leardership Style....

an organizational network includes downward communication, upward communication, horizontal communication, and cross-channel communication.

The form of organizational communication that took place at the Tahfidz Abdurrahman AlFatih, can be said to have been effective, but still not perfect. This is based on the fact that all organizational goals have not been achieved and there are still deficiencies on various sides, one of which is the cross-channel communication side. The age of the organization is still relatively young, and the number of members of the organization is still small, so the experience of this organization is still not too much. This dual assignment makes it difficult for members of the organization to determine the focus of activities, so that the goals of the organization have not been fully achieved. However, over time if the leadership style and communication patterns that are being applied now continue to be used by this organization, the effectiveness and goals of the organization will certainly be achieved properly.

\section{REFERENCES}

Arni, Muhammad. Komunikasi Organisasi. Jakarta: Bumi Aksara, 2009

Devito, Joseph. Komunikasi Antarmanusia. Jakarta: Professional Books, 1997

Fisher, Aubrey. Teori-teori Komunikasi. Bandung: Remaja Rosda Karya, 1978

Kaelan. Metode Penelitian Kualitatif Bidang Filsafat. Yogyakarta: Paradigma, 2005

Kartono, Kartini. Pemimpin dan Kepemimpinan. Jakarta : PT Raja Grafindo Perkasa, 2010

Moleong, Lexy. Metodologi Penelitian Kualitatif. Bandung: Remaja Rosdakarya, 2006

Romli, Khomsahrial. Komunikasi Organisasi Lengkap. Jakarta: Grasindo, 2011

Sendjaja, Djuarsa. Teori Komunikasi. Jakarta: Kencana, 2004

Thoha, Miftah. Pembinaan Organisasi, proses diagnosa dan intervensi, Manajemen Kepemimpinan. Yogyakarta: Gava Media, 2010

Uchayana, Onong uchyana. Dinamika Komunikasi. Bandung: PT.Remaja Rosda Karya, 2004

Umar, Husein. Strategic Management in Action, Jakarta: Gramedia Pustaka Utama, 2001

Wahjono, Sentot Imam Wahjono. Perilaku Organisasi. Yogyakarta : Graha Ilmu, 2010

Thohir, Umar Faruq. "Pemikiran Mistisisme Annemarie Schimmel." ULUL ALBAB Jurnal Studi Islam 13.2 (2012): 203-218.

Abdurrahman, Mochamad Rizki Fauzi. Komunikasi Organisasi Vertikal, Horizontal, dan Lintas Saluran Pada PT Langen Kridha Pratyangga. dalam Unpad Repository, 2017 
QAULAN, Vol. 2, No.1, Juni 2021

Rafinita Aditia, Leardership Style....

Evelina, Lidia Wati dan Mia Angeline. Komunikasi Vertikal Dan Horizontal Dalam Membentuk Gaya Kepemimpinan Berbasis Kearifan Lokal: Studi Pada Binus University. dalam Jurnal Humaniora. Vol. 5. No. 1, 2014

Hasibuan, Siti Maisarah. Pengaruh Kepemimpinan, Lingkungan Kerja dan Motivasi Kerja Terhadap Kinerja. dalam Jurnal Maneggio. Vol. 1. No. 1, 2018

Prasetia, Hendra Gilang. Hubungan Gaya Komunikasi Pemimpin dengan Kinerja Pegawai di Biro Sosial Sekretariat Daerah Provinsi Kalimantan Timur. dalam Ejournal Ilmu Komunikasi. Vol. 1. No. 2, 2009 